\title{
PENINGKATAN PEMAHAMAN KONSEP MAHASISWA PGSD UNY MELALUI MODEL TIPE SMALL GROUP DISCUSSION
}

\author{
Anantama Dewantoro ${ }^{1)}$, Ali Mustadi' ${ }^{2}$ \\ ${ }^{1}$ Pendidikan Dasar, Universitas Negeri Yogyakarta \\ email : anantamadewantoro.2017@student.uny.ac.id \\ ${ }^{2}$ Pendidikan Dasar, Universitas Negeri Yogyakarta \\ email : ali_mustadi@uny.ac.id
}

\begin{abstract}
The purpose of the research is to improve the ability to understand the concept of UNY PGSD students by applying Small Group Discussion learning methods. This research is classroom action research. The research use the Kemmis \& Mc.Taggart design. The subject in this research are 38 students of class $2 B$ PGSD UNY. The research's object is the ability to understand the concept. Data collection techniques gained through tests and observations. The conclusion of Small Group Discussion method is able to improve the conceptual understanding of UNY class $2 B$ PGSD students.
\end{abstract}

Keywords: Understanding Concept, Small Group Discussion

\begin{abstract}
Abstrak
Tujuan penelitian ini adalah untuk meningkatkan kemampuan pemahaman konsep mahasiswa PGSD UNY dengan menerapkan metode pembelajaran Small Group Discussion. Penelitian ini adalah penelitian tindakan kelas. Penelitian ini menggunakan Desain penelitian ini menggunakan disain Kemmis \& Mc.Taggart. Subjek penelitian meliputi 38 mahasiswa kelas 2B PGSD UNY.. Objek penelitian adalah kemampuan pemahaman konsep. Teknik pengumpulan data melalui tes dan observasi.. Dapat disimpulkan bahwa metode Small Group Discussion mampu meningkatkan pemahaman konsep mahasiswa PGSD UNY kelas 2B
\end{abstract}

Kata Kunci: Pemahaman Konsep, Small Group Discussion

\section{PENDAHULUAN}

Keberadaan pendidikan tinggi memegang peran yang strategis terhadap pendidikan di Indonesia. Berdasarkan UU RI No 12 Tahun 2012 Tentang Pendidikan Tinggi Pasal 1 angka 2 menyatakan bahwa Pendidikan Tinggi adalah jenjang pendidikan setelah pendidikan menengah yang mencakup program diploma, program sarjana, program magister, program doktor, dan program profesi, serta program spesialis, yang diselenggarakan oleh perguruan tinggi berdasarkan kebudayaan bangsa Indonesia. Hal ini berarti bahwa pendidikan tinggi mempersiapkan sumberdaya manusia yang cerdas, handal, kreatif dan memiliki keunggulan di bidang Ilmu dan Teknologi (IPTEK) dan kualitas Iman dan Taqwa (IMTAQ) yang kokoh.

Permasalahan yang terjadi pada Mahasiswa PGSD UNY kelas 2B ini adalah masih rendahnya pemahaman konsep tentang mata kuliah pembelajaran IPS SD. Hasil dari tes dan observasi yang dilakukan ternyata pemahaman konsep mahasiswa masih sangat rendah. Oleh karena itu diperlukanya metode pembelajaran yang 
dapat meingkatkan pemahaman konsep mahasiswa PGSD UNY kelas 2B.

Metode pembelajaran yang akan diajukan untuk meningkatkan pemahaman konsep mahasiswa adalah Strategi Small Group Discussion dalam pembelajaran, adalah salah satu strategi pembelajaran aktif dimana dalam proses pembelajaran peserta didik dibagi menjadi kelompok-kelompok kecil guna memecahkan dan mendiskusikan beberapa topik permasalahan. Topik yang didiskusikan berupa materi yang sesui dengn Standar Kompetensi dan Kompetensi Dasar.

Purwanto (2010: 51) menjelaskan bahwa pemahaman (comprehension) adalah kemampuan untuk melihat hubungan fakta dengan fakta. Menghafal fakta tidak lagi cukup karena pemahaman menuntut pengetahuan akan fakta dan hubungannya. Sudjana (2016: 24) menambahkan pemahaman dibedakan ke dalam tiga kategori. Tingkat terendah adalah pemahaman terjemahan, mulai dari terjemahan dalam arti yang sebenarnya.

Tingkat kedua adalah pemahaman penafsiran, yakni menghubungkan bagianbagian terdahulu dengan yang diketahui berikutnya, atau menghubungkan beberapa bagian dari grafik dengan kejadian, membedakan yang pokok dan yang bukan pokok.

Pemahaman tingkat ketiga atau tingkat tertinggi adalah pemahaman ekstrapolasi. Dengan ekstrapolasi diharapkan seseorang mampu melihat di balik yang tertulis, dapat membuat ramalan tentang konsekuensi atau dapat memperluas presepsi dalam arti waktu, dimensi, kasus, ataupun masalahnya.

Berbeda dengan pendapat Anderson \& Krathwohl (2015: 106-114) yang menjelaskan bahwa siswa memahami ketika mereka menghubungkan pengetahuan "baru" dan pengetahuan lama mereka. Lebih tepatnya, pengetahuan yang baru masuk dipadukan dengan skemaskema dan kerangkakerangka kognitif yang telah ada. Lantaran konsep-konsep bangunan yang di dalamnya berisi skemaskema dan kerangka-kerangka kognitif, pengetahuan konseptual menjadi dasar untuk memahami.

Lebih lanjut Anderson \& Krathwohl (2015: 100) menjelaskan bahwa memahami adalah mengkonstruksi makna dari materi pembelajaran, termasuk apa yang diucapkan, ditulis, dan digambar oleh guru. Sagala (2006: 71) menambahkan konsep diperoleh dari fakta, peristiwa, pengalaman melalui generalisasi, dan berfikir abstrak. Konsep dapat mengalami perubahan disesuaikan dengan fakta atau pengetahuan baru, sedangkan kegunaan konsep adalah menjelaskan dan meramalkan pengetahuan tersebut.

Brewer, E. W. (2007: 229) metode Strategi Small Group Discussion dalam pembelajaran, adalah salah satu strategi pembelajaran aktif dimana dalam proses pembelajaran peserta didik dibagi menjadi kelompok-kelompok kecil guna memecahkan dan mendiskusikan beberapa topik permasalahan. Topik yang didiskusikan berupa materi yang sesuai dengan Standar Kompetensi dan Kompetensi Dasar. Mills dan Alexander (2013) mendefinisikan pengajaran menggunakan model small group discussion menggambarkan sebagai keadaan di mana ada dialog dan kolaborasi di antara anggota kelompok. Hal tersebut sangat penting dan mendasar untuk belajar. Sedangkan menurut Hasibuan dan Moedjiono (2000: 20) model small group discussion berarti proses penglihatan dua atau lebih individu yang berinteraksi secara global dan saling berhadapan muka mengenai tujuan atau sasaran yang sudah tertentu melalui tukar menukar informasi, mempertahankan pendapat atau pemecahan masalah. 
Menurut Zakiyah Darajat, dkk (2001: 29) tujuan model small group discussion ialah suatu yang diharapkan tercapai setelah sesuatu usaha atau kegiatan selesai, tujuan pendidikan bukanlah suatu benda yang terbentuk tetap dan statis, tetapi merupakan suatu keseluruhan dari kepribadian seseorang berkenaan dengan seluruh aspek kehidupannya.

Hal tersebut didukung oleh Halley (2013: 118) Tujuan pembelajaran menggunakan model small group discussion adalah mengembangkan keterampilan mahasiswa dalam berbicara di depan umum, yang mengharuskan mahasiswa untuk bekerja dalam kelompok pada proyek yang dinilai tinggi, dan mendorong mahasiswa untuk mengambil kepemilikan materi pelajaran dan pembelajaran mereka sendiri.

Sedangkan menurut Melvin L. Silberman (2004: 19) Model small group discussion mengharuskan mahasiswa untuk bergabung dengan kelompok diskusi yang bertemu secara teratur selama satu semester ini, dengan masing-masing kelompok diberi tanggung jawab untuk menyajikan materi khusus yang ditugaskan ke kelas. Grup bertemu di luar kelas sebelum presentasi mereka, anggota kelompok bekerja bersama untuk menyiapkan garis besar materi dan pertanyaan diskusi. Pada hari presentasi, setiap anggota dari kelompok yang hadir diberikan kelompok diskusi. Semua mahasiswa dalam kelompok diskusi telah membaca materi, tetapi juru bicara bertanggung jawab untuk meninjau materi dengan kelompok, berdasarkan analisisnya yang lebih menyeluruh, dan untuk memimpin diskusi.

Zakiyah Darajat, dkk (2001: 27) Model small group discussion memberi mahasiswa tanggung jawab untuk mengajarkan materi kepada rekan-rekan mereka melalui pendekatan yang berpusat pada mahasiswa untuk proses pembelajaran. Model small group discussion menetapkan seluruh pelajaran untuk kelompok tertentu. Dengan menantang mahasiswa untuk menjadi fasih di bagian materi pelajaran. Sedangkan menurut Tukiran dkk (2011: 79) model small group discussion mempromosikan kepercayaan diri mahasiswa, meningkatkan pemahaman konsep, dan memberikan kesempatan untuk bekerja sebagai bagian dari tim. Diskusi yang berpusat pada mahasiswa ini sangat memungkinkan mahasiswa untuk mengembangkan pemahaman yang lebih dalam dengan mengartikulasikan argumen dalam katakata mereka sendiri.

Keberhasilan belajar dengan model belajar ini bukan semata-mata ditentukan oleh kemampuan individu secara utuh, melainkan perolehan belajar itu akan semakin baik apabila dilakukan secara bersama-sama dalam kelompok-kelompok belajar kecil yang terstruktur dengan baik. Melalui belajar dari teman sebaya dan dibawah bimbingan dosen, maka proses penerimaan dan pemahaman mahasiswa akan semakin mudah dan cepat terhadap materi yang dipelajari.

Secara umum prinsip-prinsip yang harus diperhatikan dalam strategi pembelajaran aktif yang diturunkan dari prinsip belajar menurut Melvin L. Silberman (2004: 24) adalah 1) Hal apapun yang dipelajari oleh mahasiswa, maka ia harus mempelajarinya sendiri tidak ada seorangpun yang dapat melakukan kegiatan belajar tersebut untuknya, 2) Setiap mahasiswa belajar menurut tempo (kecepatan sendiri dan setiap kelompok umur terdapat variasi dalam kecepatan belajar), 3) Seorang mahasiswa belajar lebih banyak bilamana setiap langkah memungkinkan belajar secara keseluruhan lebih berarti, 4) Apabila mahasiswa diberikan tanggungjawab untuk mempelajari sendiri, maka ia lebih termotivasi untuk belajar, ia akan belajar dan mengingat secara lebih baik. 
Dalam pembelajaran yang dimiliki dalam model small group discussion, menurut Nana Sudjana (2005: 32-35) posisi dan peran dosen harus menempatkan diri sebagai: 1) Pemimpin belajar, artinya merencanakan, mengorganisasi, melaksanakan dan mengontrol kegiatan belajar mahasiswa, 2) Fasilitator belajar artinya memberikan kemudahankemudahan mahasiswa dalam melakukan kegiatan belajarnya misal, menyediakan sumber dan alat belajar, menyediakan waktu belajar yang cukup, memberi bantuan, menunjukkan jalan keluar pemecahan masalah, menengahi perdebatan pendapat dan sebagainya, 3) Moderator belajar artinya sebagai pengatur arus belajar mahasiswa, dosen menampung persoalan yang diajukan oleh mahasiswa dan mengembalikan lagi persoalan tersebut kepada yang lain, untuk dijawab dan dipecahkan. Jawaban tersebut dikembalikan kepada kelas untuk dinilai benar salahnya, 4) Motivator belajar sebagai pendorong agar mahasiswa mau melakukan kegiatan belajar, 5) Evaluator artinya sebagai penilai yang obyektif dan komprehensif, dosen berkewajiban memantau, mengawasi, proses belajar mahasiswa dan hasil belajar yang dicapainya.

Huda (2013 : 65) dalam Small Group Discussion, mahasiswa bekerja melalui enam tahap. Deskripsi mengenai langkahlangkah Small Group Discussion adalah sebagai berikut:1) Bagi kelas menjadi beberapa kelompok kecil (maksimal 3-5 mahasiswa) dengan menunjuk ketua dan sekretaris, 2) Berikan soal yang sesuai dengan materi perkuliahan, 3) Instruksikan setiap kelompok untuk mendiskusikan materi perkuliahan, 4) Pastikan setiap anggota berpartisipasi aktif dalam diskusi, 5) Instruksikan setiap kelompok melalui juru bicara yang ditunjuk menyajikan hasil diskusinya dalam forum kelas, 6) Klarifikasi, penyimpulan dan tindak lanjut (dosen). Manfaat menggunakan small group discussion dikategorikan ke dalam dua jenis: 1) sebagai alat untuk manajemen kelas, dan 2) untuk mendorong prestasi akademik dipromosikan melalui kolaborasi (Yoshitaka, 2016).

\section{METODE PENELITIAN}

Penelitian ini menggunakan metode classroom action research atau Penelitian Tindakan Kelas (PTK). Tujuan dari penelitian ini adalah untuk meningkatkan pemahaman konsep mahasiswa PGSD Universitas Negeri Yogyakarta (UNY). Penelitian ini terdiri atas dua variable yaitu variabel terikat berupa pemahaman konsep, sedangkan variable bebasnya adalah metode small group discussion. Penelitian ini dilaksanakan di semester II kelas Konsentrasi PGSD UNY pada bulan Maretl sampai dengan bulan Juni 2018. Subyek dalam penelitian ini adalah mahasiswa semester II kelas 2B PGSD UNY yang berjumlah 38 mahasiswa. Sedangkan obyek penelitian ini adalah pemahaman konsep pada mahasiswa yang dilaksanakan dalam siklus yaitu diawali dengan melakukan perencanaan, kemudian melaksanakan tindakan dan pengamatan atau observasi, dan refleksi seperti dalam gambar berikut ini:

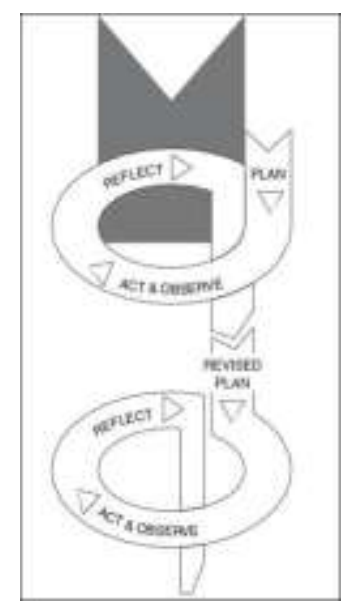

Keterangan:

Siklus I:

1. Perencanaan I

2. Tindakan dan Observasi I

3. Refleksi I

Siklus II:

1. Perencanaan II

2. Tindakan dan Observasi II

3. Refleksi II

Gambar 1. Model Spiral Kemmis Mc Taggart 
Metode pengumpulan data yang digunakan peneliti untuk memperoleh dan mengumpulkan data yang diperlukan adalah metode observasi, tes, dan dokumentasi. Sedangkan untuk pengumpulan data yang digunakan peneliti untuk memperoleh data yang diperlukan adalah hasil tes, lembar observasi, dan dokumentasi.

\section{HASIL DAN PEMBAHASAN}

Berdasarkan pembelajaran dari tindakan siklus I dan IV dengan menerapkan model small group discussion terjadi peningkatan pemahaman konsep pada mata kuliah Pendidikan IPS SD. Data yang diperoleh peneliti mengenai pemahaman konsep mahasiswa pada kelas 2B PGSD UNY dari sebelum tindakan sampai dilakukan tindakan siklus IV dapat dilihat dari tabel di bawah ini.

Peneliti ini menggunakan model Small Group Discussion yang dilaksanakan selama empat siklus. Berdasarkan pengamatan yang dilakukan oleh peneliti dalam penelitian siklus I, pemahaman konsep mahasiswa telah mengalami peningkatan. Peningkatan yang terjadi pada siklus I belum sesuai dengan prosentase dari indikator keberhasilan yang diinginkan oleh peneliti. Pemahaman konsep mahasiswa pada siklus I, siswa mampu menjelaskan sebuah konsep pada soal mengalami peningkatan beberapa siswa, siswa mampu memberikan contoh dari suatu konsep juga meningkat, sedangkan siswa menyimpulkan konsep juga mengalami peningkatan.

Hasil refleksi dari tindakan siklus I dijadikan sebagai acuan dalam perbaikan pada perencanaan tindakan siklus II, begitu seterusnya sampai dengan siklus IV. Pada tindakan siklus II, III dan IV mengalami peningkatan pada setiap indikator pemahaman konsep. Pemahaman konsep mahasiswa mengalami peningkatan disetiap siklus penelitian.

Berdasarkan tabel di atas, setiap indikator selalu mengalami peningkatan setiap siklusnya, Pada indikator ini, dari siklus 1 ke siklus 2 mengalami peningkatan sebesar $2,72 \%$. Dari siklus 3 ke siklus 4 juga mengalami peningkatan sebesar $6,66 \%$

Pada indikator advanced clarification (pemberian penjelasan lebih lanjut) selalu mengalami peningkaan di setiap siklusnya. Dari siklus 1 ke siklus 2 mengalami peningkatan 3,25\%. Dari siklus 2 ke siklus 3 mengalami peningkatan sebesar $1,04 \%$. Dari siklus 3 ke siklus 4 mengalami peningkatan sebesar 5,29\%.

Pada indikator supposition and integration selalu mengalami peningkatan pula pada setiap siklusnya. Dari siklus 1 ke siklus 2 mengalami peningkatan sebesar0,82\%. Dari siklus 2 ke siklus 3 mengaami peningkatan sebesar $12,75 \%$. Dari siklus 3 ke siklus 4 juga mengalami peningkatan sebesar $1,45 \%$.

Jika digambarkan dalam sebuah diagram akan mendapatkan hasil seperti gambar diagram dibawah. Untuk mengetahui peningkatan pemahaman konsep dan pemecahan masalah pendidikan ips siswa baik sebelum dan sesudah dilaksanakan tindakan dapat dilihat dari indikator-indikator yang dapat dijadikan sebagai penilaian. Adapun indikator- indikator yang dijadikan bahan penelitian adalah sebagai berikut :

\section{Kemampuan mahasiswa mencontohkan sebuah konsep}

Hal ini dapat dilihat dari banyaknya mahasiswa yang mampu menuliskan contoh konsep materi pada saat menyelesaikan soal. Berdasarkan hasil dari tiap siklus, pemahaman konsep mahasiswa dalam mencontohkan sebuah konsep pada soal mengalami peningkatan. 


\section{Kemampuan mahasiswa dalam menjelaskan suatu konsep}

Berdasarkan dari hasil tiap siklus, kemampuan mahasiswa dalam menjelaskan dari suatu konsep pendidikan ips sebelum dilakukan tindakan sampai dilakukan tindakan mengalami peningkatan.

\section{Kemampuan mahasiswa menyimpulkan sebuah konsep}

Indikator ini dapat dilihat dari kemampuan mahasiswa dalam menyimpulkan sebuah konsep pada soal. Dari hasil pembelajaran sebelum dilakukan tindakan sampai dilakukan tindakan siklus IV kemampuan siswa dalam menyimpulkan konsep dalam soal mengalami peningkatan

Hal ini didukung oleh pendapat Oktiana Dwi (dalam Zulkardi, 2003:7) yang menyatakan bahwa mata pelajaran pendidikan ips menekankan pada konsepkonsep, artinya dalam mempelajari pendidikan ips harus dapat memahami konsep pendidikan ips terlebih dahulu agar mampu menyelesaikan soal-soal dan mampu mengaplikasikan pembelajaran tersebut kedalam kehidupan nyata.

Pembelajaran dengan metode Small Group Discussion merangsang mahasiswa untuk berpikir lebih dalam tentang konsep yang diajarkan. Dengan adanya diskusi dan berkelompok akan memberikan kesempatan setiap mahasiswa untuk mengembangkan pemahaman konsep mereka.

Berdasarkan pembahasan hasil penelitian diatas, maka dapat dikatakan bahwa dengan menerapkan metode Small Group Discussion dapat meningkatkan pemahaman konsep mahasiswa semester II kelas 2B program studi PGSD Universitas Negeri Yogyakarta (UNY).

Tabel 1. Hasil Riset Kemampuan Pemahaman Konsep Mahasiswa Per Indikator

\begin{tabular}{|l|c|c|c|c|}
\hline Indikator Pemahaman Konsep & Siklus I & Siklus II & Siklus III & $\begin{array}{l}\text { Siklus } \\
\text { IV }\end{array}$ \\
\hline $\begin{array}{l}\text { Mahasiswa memberikan contoh dari } \\
\text { suatu konsep }\end{array}$ & $74,76 \%$ & $77,48 \%$ & $76,77 \%$ & $83,33 \%$ \\
\hline $\begin{array}{l}\text { Mahasiswa mampu menjelaskan } \\
\text { suatu konsep }\end{array}$ & $73,33 \%$ & $76,58 \%$ & $77,62 \%$ & $82,91 \%$ \\
\hline $\begin{array}{l}\text { Mahasiswa mampu menyimpulkan } \\
\text { suatu konsep }\end{array}$ & $53,57 \%$ & $54,39 \%$ & $67,14 \%$ & $68,59 \%$ \\
\hline
\end{tabular}

\section{Gambar 1. Hasil Riset Pemahaman Konsep Mahasiswa Per Indikator}

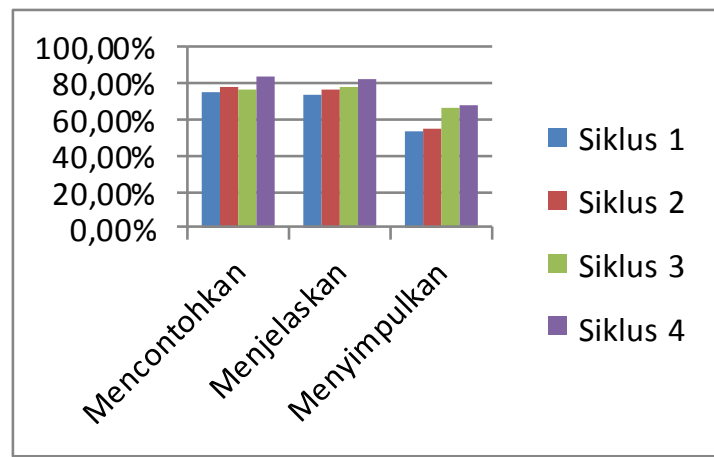




\section{SIMPULAN}

Berdasarkan temuan penelitian dan pembahasan hasil penelitian, maka dapat disimpulkan ketika perkuliahan menggunakan metode small group discussion dapat meningkatkan pemahaman konsep mahasiswa. Dengan kegiatan tersebut mahasiswa akan terbiasa mengemukakan pendapat, bertukar pemikiran, dan percaya diri sehingga mampu meningkatkan pemahamans $=$ suatu konsep.

\section{DAFTAR RUJUKAN}

Anderson, L. W. \& Krathwohl, D. R. (2015). Kerangka Landasan Untuk Pembelajaran, Pengajaran dan Asesmen. Yogyakarta: Pustaka pelajar

Bennett J, Lubben F, Hogarth S, Campbell B. (2004). A systematic review of the use of small-group discussions in science teaching with students aged 11-18, and their effects on students' understanding in science or attitude to science. In: Research Evidence in Education Library. London: EPPI-Centre, Social Science Research Unit, Institute of Education, University of London.

Brewer, E. W. (2007). 13 Proven ways to get your message accros; the essential reference for teachers, trainers, presenters, and speaker. In 13 Proven Ways to Get Your Message Accros; The Essential Reference fo Teachers, Trainers, Presenters, and Speaker. California: Corwin Press, 225-234
Choe, S. W. T., \& Drennan, P. M. (2001). Analyzing scientific literature using a jigsaw group activity. Journal of College Science Teaching, 30, 32830.

Hamalik, Oemar. 2008. Proses Belajar Mengajar. Jakarta: Bumi Aksara, 2008.

Hasibuan \& Moedjiono. 2000. Proses Belajar Mengajar. Bandung: Remaja Rosdakarya.

Halley, Jean; Heiserman, Courtney; Felix, Victoria \& Eshleman, Amy. 2013. Students Teaching Students: $\quad$ A Methodfor Collaborative Learningm, 1(3), 1-20.

Herawati, Oktiana Dwi Putra. 2010. "Pengaruh pembelajaran Problem Posing terhadap Kemampuan Pemahaman Konsep Pendidikan IPS SD Mahasiswa Kelas PGSD UAD”. Jurnal Pendidikan Matematika. Vol.4, No.1, Juni 2010.

Huda, Miftahul. 2013. Cooperative Learning. Yogyakarta: Pustaka Pelajar

Ismail. 2008. Strategi Pembelajaran Agama Islam Berbasis PAIKEM. Semarang: RaSail Media Group.

Kato, Yoshitaka. 2016. What Do We Want Small Group Activities For? Voices from EFL Teachers in Japan. TESL-EJ, 19(4), 1-15.

Kaylene C. Williams and Caroline C. Williams. 2011. "Five key 
ingredients for improving student motivation". Research in Higher Education Journal, 165-174

Melvin L. Silberman. 2004. Active Learning: 101 Cara Belajar Siswa Aktif. Bandung: Nusa media.

Mills, D., \& Alexander, P. (2013). Small Group Teaching: A Toolkit for Learning. Higher Education. Heslington: The Higher Education Academy.

Perkins, D. V., \& Saris, R. N. (2001). A 'jigsaw classroom' technique for undergraduate statistics courses. Teaching of Psychology, 28(2), 111-113. doi:10.1207/S15328023TOP2802 09

Purwanto. (2010). Evaluasi Hasil Belajar. Yogyakarta: Pustaka Pelajar

Raja, N., \& Saeed, A. (2012). The effectiveness of group work and pair work for students of English at undergraduate level in public and private sector colleges.
Interdiciplinary Journal of

Contemporary Research In

Business, 4(5), 155-163.

Sagala, S. (2006). Konsep dan Makna Pembelajaran. Bandung: Alfabeta.

Sudjana, N. (2016). Penilaian Hasil Proses Belajar Mengajar. Bandung: Remaja Rosdakarya.

Sudjana, Nana. 2005. CBSA dalam Proses Belajar Mengajar. Bandung: Sinar Baru Algesindo.

Taniredja, Tukiran dkk. 2011. Model Model Pembelajaran Inovatif. Bandung: Alfabeta

Zakiyah Darajat, dkk. 2001. Ilmu Pendidikan Islam. Jakarta : Bumi Aksara. 